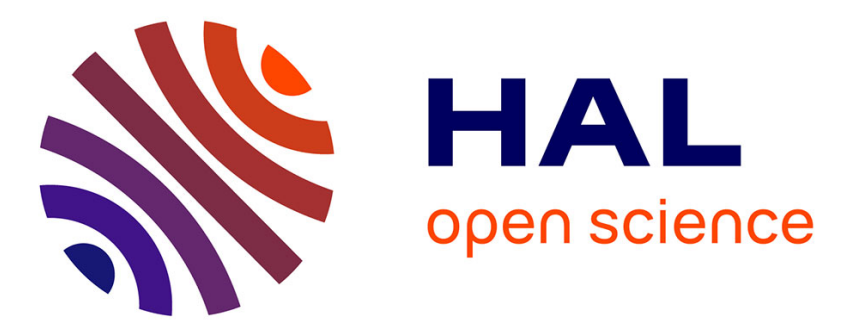

\title{
The differentiated impacts of organizational innovation practices on technological innovation persistence
}

Christian Le Bas, Caroline Mothe, Thuc Uyen Nguyen-Thi

\section{To cite this version:}

Christian Le Bas, Caroline Mothe, Thuc Uyen Nguyen-Thi. The differentiated impacts of organizational innovation practices on technological innovation persistence. European Journal of Innovation Management, 2015, 18 (1), pp.110-127. 10.1108/EJIM-09-2012-0085 . hal-01301433

\section{HAL Id: hal-01301433 \\ https://hal.univ-grenoble-alpes.fr/hal-01301433}

Submitted on 12 Apr 2016

HAL is a multi-disciplinary open access archive for the deposit and dissemination of scientific research documents, whether they are published or not. The documents may come from teaching and research institutions in France or abroad, or from public or private research centers.
L'archive ouverte pluridisciplinaire HAL, est destinée au dépôt et à la diffusion de documents scientifiques de niveau recherche, publiés ou non, émanant des établissements d'enseignement et de recherche français ou étrangers, des laboratoires publics ou privés. 


\title{
The differentiated impacts of organizational innovation practices on technological innovation persistence
}

\author{
Christian Le Bas, Caroline Mothe, Thuc Uyen Nguyen-Thi
}

\begin{abstract}
Purpose

This article tests the major determinants of technological (product and process) innovation persistence and provides evidence of the significant role of organizational innovation.

\section{Design/methodology/approach}

Data came from two waves of the Luxembourg Community Innovation Survey (CIS): CIS2006 for 2004-2006 and CIS2008 for 2006-2008. The longitudinal data set resulted in a final sample of 287 firms. A multinomial probit model estimates the likelihood that each firm belongs to one of three longitudinal innovation profiles: no, sporadic, or persistent innovators.
\end{abstract}

\section{Findings}

The determinants have differentiated impacts on process and technological innovation persistence. Organizational innovation influences technological innovation persistence. In the analysis of detailed organizational practices, strong evidence emerged that knowledge management exerts a crucial effect on product innovation persistence; workplace organization instead is associated with process innovation persistence.

\section{Research limitations/implications}

The relationships of innovation persistence, organizational innovation, and firms' economic performance demand further exploration. The different persistence patterns of complex (process and product) and simple (process or product) innovators also are worth investigating.

\section{Practical implications}

Organizational innovation matters for technological innovation persistence. However, the effects of non-technological innovation differ depending on whether the firm wants to innovate in processes or products. Managers must acknowledge these various effects and select appropriate strategies.

\section{Originality/value}

Few works account for the impact of organizational innovation strategies on technological innovation. This study is the first, based on recent CIS data, to address the role of organizational innovation practices for technological innovation persistence, which appears necessary for the sustainable dynamics of firms, industries, and regions.

Article type: Research paper 
Keywords: Persistence; Innovation; Technological innovation; Organizational innovation; R\&D JEL classification: L25, O31, O32 


\section{INTRODUCTION}

Innovation persistence has been an important topic for applied industrial organization studies since the publication of Geroski et al.'s (1997) work. Subsequent empirical studies (Antonelli, 2011; Colombelli and von Tunzelmann, 2011; Dosi, 1997) offer increasing recognition that firms' competitive advantage largely depends on their ability to innovate over time. In the evolutionary tradition, sustainable growth is linked to firms' capacity to accumulate economically useful technological knowledge (Nelson and Winter, 1977; Pavitt, 2003). For the economy as a whole, the objectives differ slightly, because some part of productivity growth can stem from the creation of new firms that implement new products or process technologies.

To assess innovation persistence empirically, observations of innovation must span different time periods. Consistent with Geroski et al. (1997), we define a firm's degree of innovation persistence as the number of consecutive years during which it has a recorded innovative output. A firm instead innovates sporadically if it does so in some periods but not in others. When it does not innovate over several time periods, it is non-innovative.

Various studies of persistence offer somewhat contradictory results, and no general survey has provided a synthesis of knowledge on this phenomenon. Therefore, this article gathers critical relevant evidence from prior research; as its main objective, it highlights the role of organizational innovation in technological innovation persistence, an effect that often has been neglected in empirical research. As our main research question, we seek to determine the main determinants of technological innovation persistence. For this effort, we define innovation as the adoption of an idea, behaviour, system, policy, program, device, process, product, or service that is new to the organization. Thus organizational innovation refers to all parts of the organization, but innovation also can pertain specifically to technological or organizational forms. Technological innovation in turn encompasses product and process innovations. Therefore, we consider the distinct types of innovation and accordingly distinguish three innovation statesrecurrent non-innovator, sporadic innovator, and persistent innovator-to identify the specific determinants of each of these three different profiles. We devote particular attention to organizational innovation as a main determinant.

Our main motivation for pursuing this question is the lack of research examining the various innovation strategies that firms might adopt to produce innovations in organizational practices. This gap is even more surprising considering that previous innovation literature frequently highlights the iterative nature of innovation processes and the critical role of nontechnological activities. This type of innovation could have substantial impacts on technological innovation, in that it tends to change the factors (e.g., $R \& D$ investment) that determine technological innovation - which in turn defines firm performance. Not all firms are R\&D intensive, and various studies demonstrate that organizational skills can influence technological innovation performance (e.g., Lokshin, van Gils, and Bauer, 2008; Mothe and Nguyen-Thi, 2010).

Yet to date, only one study systematically investigates whether firms engage in persistent organizational innovation. Ganter and Hecker (2013) reject this notion but also fail to analyse any potential link with technological innovation. In addition, though Le Bas and Poussing (2013) find that organizational innovation is statistically significant for complex innovators, to the best of our knowledge, no study investigates the potential impact of organizational innovation on firms' technological innovation persistence. Unlike Le Bas and Poussing (2013), we explicitly 
distinguish three states of innovation behaviour (i.e., persistent, sporadic, and non-innovator), and we apply three types of organizational innovation as independent variables.

Accordingly, the present research highlights the effects of non-technological innovation strategies on firms' technological innovation persistence. Our work thus constitutes a response to Armbruster et al. (2008), who call for further investigations to clarify distinct types of innovation, especially organizational innovation. To advance a research tradition that has started to study the links of organizational and technological innovations but remained silent about the impact of organizational innovation on persistent technological innovation behaviour, we move beyond a static or cross-sectional data set. That is, we use two successive waves of the Luxembourg Community Innovation Survey (CIS), such that our study addresses the directions of causality and endogeneity issues. With empirical evidence from the Luxembourg CIS, we also extend knowledge about the main determinants of both product and process innovation persistence. In particular, we show that organizational innovation has a strong positive impact on firms' likelihood of persisting in their product innovation efforts.

In Section 2 we examine the impact of non-technological innovation on technological innovation persistence. Section 3 contains the outline of the data set, variables, and method. We present the results, which show that organizational innovation exerts varying impacts, depending on the innovation profiles and type of technological innovation (product or process). On the basis of these considerations, in Section 4 we conclude and suggest avenues for further research.

\section{TECHNOLOGICAL INNOVATION PERSISTENCE: LITERATURE AND HYPOTHESES}

For this study, we consider both organizational and technological (product and process) innovation and review existing analytical frames and empirical studies that deal with the determinants of innovation persistence. We then offer hypotheses about the influence of organizational innovation.

\subsection{Three main frame of analysis}

Using three analysis frames-resource constraints, sunk costs, and competence-we characterize innovation persistence according to its causes and consequences, as well as to the most important underlying mechanisms. We adopt the useful taxonomy suggested by Ganter and Hecker (2013), which is similar to that used by Le Bas and Scellato (2013).

In a resource constraint perspective, the focus is on "the observation that firms frequently face serious financial constraints in funding their innovation projects. Innovation activities are often capital-intensive, risky, and difficult for external financers to assess" (Ganter and Hecker, 2013: 1432). For the firm to achieve successful innovation over a certain period of time, it must have sufficient internal cash flows to fund its R\&D spending. Flaig and Stadler (1994) propose insights related to this approach that they refer to as the success-breeds-success hypothesis, such that innovation increases firm profitability, which in turn funds additional R\&D activities. A firm with sufficient creativity thus will innovate persistently (see Latham and Le Bas, 2006), and its prior commercial successes exert an important influence. Antonelli et al. (2012) show that previous innovations have a long-lasting effect on profitability. Therefore, we anticipate a critical 
relationship between persistence in innovation and the persistence of above-average profits (Cefis, 2003; Cefis and Ciccarelli, 2005).

The sunk cost perspective instead argues that firms that decide to invest in R\&D activities must incur start-up costs that usually are not recoverable (Antonelli et al., 2012). These sunk costs bar both entry to and exit from R\&D activity, such that they create strong motives to enter and remain within a specific $R \& D$ activity regime. According to this approach, innovation persistence results from intertemporal stability in R\&D efforts. Similar arguments serve to explain why non-innovators also persist in their non-innovating behavior.

Finally, Ganter and Hecker (2013) offer a competence-based perspective as a third explanation for firms' innovation persistence. This view stipulates that technological innovation is associated with dynamically increasing returns, in the form of learning-by-doing and learning-to-learn, which enhance knowledge stocks and the probability of future innovations (Duguet and Monjon, 2002; Geroski, Van Reenen, and Walters, 1997; Latham and Le Bas, 2006). Learning establishes the capacity to innovate later (Cohen and Levinthal, 1989). Thus, through its R\&D, the firm explores a process of learning and discovers useful new ideas, by recombining and rearranging existing notions. That is, past innovation affects current innovation (Duguet and Monjon, 2002; Geroski et al., 1997). This perspective provides the most appropriate approach for this research.

\subsection{Technological innovation persistence: empirical trends}

Several empirical studies consider the scale and scope of innovation persistence. Innovation can be measured with different types of indicators, such as patents, major innovations, or R\&D outputs, as well as according to various databases such as the CIS. For example, in a highly influential study, Geroski et al. (1997) examine the innovative history of UK firms by studying a patent database. They find that the number of patents granted at the beginning of an innovative period, which they refer to as a spell, is a good predictor of the length of such spells. The main determinant of innovation persistence thus may be the size of the "innovation activity," rather than the extent of "economic activity." In Le Bas et al.'s (2003) empirical analysis of French firms that made patent applications with the US Patent Office between 1969 and 1985, they show that a minimum threshold of innovation activity (i.e., minimum patenting) is necessary to gain status as a "persistent innovator." That is, only consistent innovators could become persistent innovators. Finally, Duflos (2006) investigates innovation persistence using patent data and finds that innovative activity at the firm level depends strongly on the technological importance of prior innovations (i.e., the value of prior innovations).

Data describing major innovations appear to be more insightful for assessing innovation persistence than patent counts though, because they support a focus on firms that are technically innovative and commercially successful. The use of such data has been sparse thus far, largely because of the very high costs involved in gathering relevant data over time and across many technological fields. Geroski et al. (1997) thus supplement patent data with SPRU (Science and Technology Policy Research) data related to major innovations (as provided by experts) to explore innovation persistence and seek evidence consistent with the view that not many firms innovate persistently. Their findings confirm that very few innovative firms are persistently innovative. Larger firms (measured by employment) tend to have longer innovation spells, yet even this relationship between firm size and spell length appears non-linear (Geroski et al., 1997). Furthermore, few studies use R\&D indicators to track innovation persistence (e.g., Máñez 
Castillejo et al., 2004). Instead, most investigations use R\&D expenditures as an independent variable to control for the possible effects of formal industrial research on the origins of innovation persistence (Duguet and Monjon, 2004).

The use of homogeneous CIS data instead is becoming more widespread, largely because they effectively facilitate international comparisons. These data sets provide information about innovation at the firm level, without any reference to commercial success or likely patenting status. The statistical category related to innovation is based mostly on the so-called Oslo Manual. Duguet and Monjon (2004), in a study of 808 French industrial firms' innovative activity during 1986-1996, find that innovation persistence is strong. Around $50 \%$ of the innovating firms in one period continued to innovate one or two periods later. A firm that already innovated in the past also exhibited stronger probabilities of innovating in the future. Raymond et al. (2010) measure innovation intensity with the ratio of innovative to total sales. From three CIS waves describing Dutch manufacturing firms, they conclude that past shares of innovative sales weakly condition current shares of innovative sales. They caution against the blind use of this approach though, because two types of state dependence exist: true state dependence, in which prior past innovation enhances the probability of innovating in the current period, and spurious state dependence, in which unobserved effects are correlated over time. Haned (2011) uses four waves of the French CIS (1994-2006) to show that the frequency of innovation activity in the past exerts a strong, significant influence on current innovation activity. In all these estimations, a higher coefficient emerges for firms that innovated in each of the three prior periods.

The rich frame of the CIS supports investigations of not just whether the firm innovates over time but also the type of innovation, such that it becomes possible to analyze trends in innovation persistence for a particular type of innovation. For example, some investigations differentiate only between process or product innovators, whereas others consider whether a firm is a single persistent innovator in products or in processes. Haned (2011) finds that the coefficients of the lagged explanatory variables accounting for the frequency of past innovations are stronger and more significant for product innovators than for process innovators, such that the persistence trend is stronger for product innovators. These results align with the findings of Antonelli et al. (2010), who show that the level of persistence is higher for product innovators (Clausen et al., 2010; Roper and Hewitt-Dundas, 2008). Other investigations refer to complex innovators, who innovate in both products and processes. Le Bas and Poussing (2013), using data from the Luxembourg CIS, show that complex innovators are more persistent (as innovators) than single innovators of either type. Accordingly, we explicitly account for each firm's innovative activity in products and in processes separately.

\subsection{The neglected role of organizational innovation}

Both theoretical and empirical studies devote limited attention to other innovation strategies, such as those implemented in non-technological fields, even though enlarging the analysis of innovation beyond the technological domain provides a much richer and complex picture of firm's innovation strategies and performances (Evangelista and Vezzani, 2010). The authors demonstrate the important role played by organizational changes as a driver of firms' performance and reveal that firms introducing both technological and organizational innovations 
enjoy a clear competitive advantage with respect to both non-innovating firms and firms that adopt narrower approaches to innovation.

Theoretically, organizational innovation is a broad concept that encompasses strategies, as well as structural and behavioural dimensions. According to the OECD (2005), an organizational innovation is the implementation of a new organisational method in the firm's business practices (including knowledge management), workplace organization or external relations that has not been previously used by the firm. It must be the result of strategic decisions taken by management. Most studies focus on the conventional pathway by which technological innovation leads to organizational innovation, but emergent research also emphasises the role of organizational innovation for enhancing flexibility and creativity, which in turn facilitate developments of technological innovation. Bharadwaj and Menon (2000), using data collected from 634 firms, support the organizational innovation hypothesis that innovation is a function of individual efforts and organizational systems designed to facilitate creativity, such that successful product innovation depends partly on organizational factors. Lokshin et al. (2008) consider fast-moving consumer goods firms in Germany and find complementarity between organizational skills and technological innovation: Firms that successfully combine customer, technological, and organizational skills bring more product innovations to market, which highlights the crucial role of organizational practices in technological innovation. Corrocher et al. (2009) also note that some Italian KIBS (KnowledgeIntensive Business Services) firms are characterized by an innovation domain that revolves around techno-organizational change, in which technological and organizational innovations are interrelated. We therefore expected to observe a positive likelihood of co-occurrence between organizational and technological innovations. Firms dedicating more resources to managerial practices or new organizational forms should be in better positions to use new skills and technologies more efficiently.

Yet few works investigate the potential impact of organizational innovation on firm innovation persistence (cf. Antonelli et al., 2010; Le Bas and Poussing, 2013). That is, even as studies have been highlighting the importance of technological innovation as a driver of organizational change within the firm for years (Dougherty, 1992; Henderson and Clark, 1990), the inverse relationship may be in effect, such that organizational innovation enhances flexibility and creativity, which facilitate the development of technological innovation. Lokshin et al. (2008) even show empirically that firms that combine customer and organizational skills tend to introduce more technological innovations, as confirmed by Mothe and Nguyen-Thi (2010, 2011). In line with these works, we regard organizational practices as potential input to the firm's innovation process and thus to innovation persistence, and we develop two major hypotheses (see Figure 1 for the theoretical model):

Hypothesis 1: A firm is more likely to persist in product innovation if it pursues organizational innovation.

Hypothesis 2: A firm is more likely to persist in process innovation if it pursues organizational innovation. 
Figure 1: Theoretical model

\begin{tabular}{|c|l|}
\hline \multirow{2}{*}{$\begin{array}{l}\text { Organizational innovation } \\
\text { Knowledge } \\
\text { management systems }\end{array}$} & $\begin{array}{l}\text { Technological innovation persistence } \\
\text { (three profiles: recurrent non } \\
\text { innovator, sporadic innovator, and } \\
\text { persistent innovator) } \\
-\quad \begin{array}{l}\text { Work organization } \\
-\quad \text { External relations }\end{array}\end{array}$ \\
\hline
\end{tabular}

To test these hypotheses, we consider the impacts of three types of organizational innovation practices. First, organizational innovation refers to the introduction of knowledge management (KM) systems, such as management skills or sharing, coding, and storing knowledge, usually associated with greater flexibility, adaptability, competitive advantage, and organizational performance (Alänge and Steiber, 2011; Grant, 1996; Prahalad and Hamel, 1990; Spicer and Sadler-Smith, 2006). Various studies recognize the positive impact of KM strategies but offer little conclusive evidence (Becerra-Fernandez and Sabherwal, 2001), such that some contributions even report a weakly significant relationship (Chen et al. 2004). Shin (2004) argues that the high costs generated by the implementation of such a strategy may impede a firm's performance, though Kremp and Mairesse (2004) find that firms with KM policies likely innovate more extensively and achieve higher productivity. Uhlaner et al. (2007) also show, for a panel of Dutch firms, that firms that implement KM attain greater growth.

Second, in relation to changes to the work organization, the OECD (2005) cites several new work practices, such as lean and just-in-time production, decentralized decision-making, teamwork, and shared rewards. Implementing a new work organization could lead to substantial improvements in organizational flexibility, which in turn increases firm efficiency and performance. Previous empirical studies offer controversial results regarding the benefits of such changes in the work organization though. According to Ichniowski et al. (1997), among a sample of 36 homogeneous steel production lines, using innovative work practices such as teams, flexible job assignments, and training increases output levels and product quality. Yet Bresnahan et al. (2002) highlight the complementary nature of product and service innovations, information technology, and workplace reorganization, such that they assert new work practices result in improvements in firm performance only when they combined with heavy investments in human capital or information and communication technology.

Third, external relations with other firms or public institutions can occur through alliances, partnerships, outsourcing, or subcontracting. Vertical cooperation with customers and suppliers theoretically should enhance firm efficiency by reducing uncertainty related to the introduction of new products or services to the market, contributing vital information about technologies and changing market needs, and facilitating market expansion-particularly if the innovation is new or complex (Klomp and van Leeuwen, 2001; von Hippel, 1988). Firms may also cooperate with universities and research institutes to gain new scientific and technological knowledge, such as through technology evaluation initiatives, the anticipation of social effects, access to equipment and techniques, or new technological options. 


\subsection{Data set, variables, and methodology}

Even as interest in technological innovation and its persistence has increased, its link with organization innovation remains a black box (see Mothe and Nguyen-Thi, 2012). To fill this gap, we use data stemming from two waves of the Luxembourg Community Innovation Survey (CIS): CIS2006 for 2004-2006 and CIS2008 for 2006-2008. These surveys were coordinated by EUROSTAT and carried out by CEPS/INSTEAD, ${ }^{1}$ in collaboration with STATEC. ${ }^{2}$ The first survey, CIS2006, encompassed 1491 enterprises: 320 from the manufacturing sector and 1158 from the service sector. The target population covered $99.5 \%$ of Luxembourg firms. A sample of 644 firms received the questionnaire (220 manufacturing and 411 service firms). Due to the very high response rate $(88 \%)$, a no-response survey was not necessary. After correcting for unusable responses, we used a final sample of 568 firms with more than 10 employees (the CIS target population), functioning in manufacturing (212 firms, 37\% of the total) and service (356 firms, $63 \%$ ) sectors. The second survey, CIS2008, contained a sample of 615 firms with more than 10 employees, 405 in services $(65.9 \%)$ and 210 in manufacturing $(34.1 \%)$. Of these firms, 52\% employed between 10 and 49 people, $35 \%$ between 50 and 249, and $13 \%$ had more than 249 employees.

These recent surveys are homogenous in their definitions of innovation, so we can identify identical questions related to product and process innovations. By merging the two waves, we constructed a longitudinal data set of firms that had been interviewed in both surveys. The merged sample features characteristics of a balanced panel of 287 representative firms for a period from 2004 to 2008 (53\% in services, $47 \%$ in manufacturing). This data set reveals a large set of organizational practices implemented in the past, such that we can control for the role of non-technological factors for determining innovation persistence and account for the substantial time lag that usually is associated with the return on investment of medium- to long-term innovation strategies.

3.1.1. Dependent variables. To study the effect of organizational innovation strategies on technological innovation through product and process innovations, we defined two binary dependent variables, on the basis of a "yes-no" question about whether the firms introduced new or significantly improved products between 2004 and 2006 (CIS2006) and between 2006 and 2008 (CIS2008). On the basis of these two binary variables, we built a new variable, "innovation profiles", that captures three innovation states: recurrent non-innovator, which is equal to 0 and indicates that no product (process) innovation was introduced over the entire five-year period; sporadic innovator, taking a value of 1 , such that the firm has introduced a product (process) innovation during one of the two reference periods; and persistent innovator, equal to 2 if the

\footnotetext{
${ }^{1}$ International Network for Studies in Technology, Environment, Alternatives, Development.

${ }^{2}$ Central Service of Statistics and Economic Studies.
} 
firm has continuously introduced product (process) innovations in both reference periods, 20042006 and 2006-2008. We used a multinomial probit model to estimate the likelihood that a firm belongs to each of the three innovation profiles. Therefore, we could investigate the correlations of the different innovation profiles, conditional on organizational innovation and a set of explanatory variables. All the variables relate to the first time period (CIS2006). Our underlying hypothesis predicts a close relationship between innovation activities implemented in the past and technological innovation, such that organizational innovation should be crucial for explaining the persistence of technological (product or process) innovation.

3.1.2. Main independent variable: Organizational innovation. Previous analyses that examine the impact of organizational innovation on technological innovation use several measures of organizational innovation (Mothe and Nguyen-Thi, 2010, 2012). They have mainly investigated this relationship during a specific reference period, rather than the impact of previous introductions of organizational practices on subsequent technological innovation behaviour. For this study, we measure organizational innovation with three lagged variables, which we define in Tables 1 and 2: (1) new business practices and knowledge management, (2) new methods of workplace organization, and (3) new methods of organizing external relations. These binary variables each equal 1 if the firm has introduced related practices between 2004 and 2006, and 0 otherwise. A total of $43 \%, 38 \%$, and $27 \%$ of innovative firms implemented new KM systems, methods of workplace organization, and methods of organizing external relations, respectively. We also introduced a composite measure of organizational innovation, taking a value of 1 if firms adopted at least one of these practices and 0 otherwise.

For explanatory variables, $R \& D$ expenditures commonly appear in prior literature as a main determinant of innovation persistence (Clausen et al., 2010; Johansson and Lööf, 2010; Triguero-Cano and Corcoles-Gonzalez, 2010). Máñez Castillejo et al. (2004) highlight the existence of sunk costs in firms' $R \& D$ activities and indicate that these sunk costs explain the persistence of $R \& D$ activities (a barrier to both entry to and exit from $R \& D$ activities). Prior R\&D or innovation activity also affects the current probability of innovating (Lelarge, 2006). ${ }^{3}$ To address this evidence, we include an $R \& D$ intensity variable, defined as $R \& D$ expenditures per employee by firms that reported engaging R\&D activities during 2004-2006.

We also controlled for proximity to science sources. In both CIS surveys, firms rated the importance of different external sources of information for their innovation activities. The dummy variable science sources is coded as 1 if sources of information stemming from institutional research (universities, other higher education institutions, government, public research institutes) are crucial for firm innovation activities and 0 otherwise. In the sample, 29\% of the observations indicate the crucial importance of science sources.

Two binary variables refer to appropriability conditions. Strategic protection is equal to 1 if firms rank the importance of the three strategic protection methods-"secrecy", "complexity

\footnotetext{
${ }^{3}$ According to Antonelli et al. (2010), Huang (2008), Musolesi (2006), and Peters (2009), the probability of further innovations is affected by the sequence of innovations introduced in the past. Duflos (2006) finds that present success depends on the technological importance of past innovation.
} 
of design" or "lead-time advantage over competitors"-as "crucial" and 0 otherwise. Formal protection is equal to 1 if the importance of the formal protection methods, including "patents", "trademarks", "registration of design patterns" or "copyrights", ranked as "crucial" and 0 otherwise.

The fiercer the competition, the more firms are likely to innovate persistently (Antonelli et al., 2010; Máñez Castillejo et al., 2004). In effect, firms in more competitive markets have greater incentives to undertake R\&D activities. In the CIS, firms rated the degree of competition in their markets, using a Likert scale from 0 (no effective competition) to 3 (very intensive). On the basis of this information, we constructed the competition intensity variable.

As control variables, we introduced firm size, measured by the natural logarithm of the number of employees. The larger the firm, the more important persistence becomes, because large firms should have more market power (Huang and Yang, 2010) and more capacity to exploit innovations (Clausen et al., 2010; Peters, 2009). Antonelli et al. (2010) explain that smaller firms face stronger entry than exit barriers. We also introduced a dummy variable for group belonging, equal to 1 if the firm belongs to a group and 0 otherwise. Johansson and Lööf (2010) and Raymond et al. (2010) explain that belonging to a multinational or being part of a group could influence persistence.

The technological opportunity the firm confronts is a key determinant of its innovation persistence. Firms that function in high technology or scientific industries (Huang and Yang, 2010) have more chances to innovate persistently. Lelarge (2006) and Raymond et al. (2010) cite a technological frontier: Industries that are closer to the technological frontier are more likely to display innovation persistence. Furthermore, persistence could be influenced by the sectoral affiliation of the firm (Antonelli et al., 2010) or the market structure, such as a highly concentrated industry (Cefis and Ciccarelli, 2004) or markets with more demand pull (Raymond et al., 2010). For this study, we use activity sectors to proxy for technological opportunity. We thus refine the sub-sector dummies according to the two-digit NACE (statistical classification of economic activities). For manufacturing, the two sub-sectors reflected the OECD (2001) definition: high-technology industries or medium- and low-technology industries. For services, we used four sub-sector dummies: (1) R\&D engineering activities and consultancy, technical testing and analysis; (2) computer activities; (3) financial activities; and (4) wholesale trade, transport and communication. In Tables 1-3, we detail these variables and their descriptive statistics.

\section{TABLES 1, 2 and 3 HERE}

\subsection{Estimation results}

Table 4 contains the results of the multinomial probit estimation for all dependent variables. Using a corresponding likelihood ratio test, we confirmed the appropriateness of using a multinomial probit model rather than individual probit estimations to reject the hypothesis that the error terms are uncorrelated. The results show that the aggregated measure of organizational innovation has a strong positive impact on firms' likelihood of being persistent in product innovation compared with the profile of non-innovation recurrence. We also observed that sporadic and organizational innovations are closely associated with the non-innovation profile. 
These results support the notion that non-technological innovation is a specific determinant of product innovation as a whole, not just its persistence. In contrast, organizational innovation matters most for sporadic process innovation, with no apparent effect on process innovation persistence.

\section{TABLE 4 HERE}

Regarding individual practices, $\mathrm{KM}$ practices that facilitate the use of external information and internal skills effectively increase the likelihood of persistent or even just sporadic product innovation. This finding corroborates the idea that KM strategies are associated with more flexibility, adaptability, and competitive advantage. Firms have opportunities to increase their innovation capacity when they expand, disseminate, and exploit organizational knowledge internally, as well as when they share, transfer, and receive knowledge from external partners (Spicer and Sadler-Smith, 2006). We find no evidence related to process innovation. These results support the prediction that KM practices, such as business re-engineering, quality management, or employees' up-skilling, are crucial for innovativeness in goods and services rather than for improving process methods or supporting activities.

In contrast, the introduction of new or improved workplace organization methods, such as decentralized decision-making, teamwork, or shared rewards, has a positive, strongly significant impact on both persistent and sporadic profiles of process innovators, compared with nonrecurrent profiles. External relations through alliances, partnerships, outsourcing, or subcontracting are significant for product innovation, in line with previous results that highlight the importance of external relationships for technological innovation (Evangelista, 2000; Love and Mansury, 2007). We also found a negative, significant impact of these practices on process innovation persistence. In other words, firms implementing external relations during the previous period are less likely to persist in their process innovation, relative to recurrent non-innovators. Perhaps through various types of external partnerships, firms collaborate to implement product innovations (usually protected by patents) but prefer not to collaborate to improve its processes, because they do not want to share information about their processes with any external entities.

The results also show, as expected, that firms that invested intensively in R\&D in the past are more likely to innovate continuously in products and processes during 2004-2008. Our results might reflect two explanations, matching the analytical frameworks that seek to account for firms' technological innovation persistence. First, according to the knowledge accumulation hypothesis, experience in innovation is associated with dynamically increasing returns, in the form of learning-by-doing and learning-to-learn effects (Duguet and Monjon, 2002; Geroski et al., 1997; Latham and Le Bas, 2006). By innovating, the firm explores a process of learning and discovers new ideas by recombining old ones. In so doing, the firm prepares for future innovations. In particular, innovations in $\mathrm{KM}$ increase the creativity of $\mathrm{R} \& \mathrm{D}$ teams and feed innovation persistence, which should have fruitful short-term consequences. Second, according to the success-breeds-success hypothesis, innovation improves firm profitability, which then funds subsequent innovation activities (Flaig and Stadler, 1994). In this case, economic and commercial successes are crucial. Organizational innovations increase firm productivity, which improves the firm's competitive advantages and profitability. To some extent, they provide a means to invest more in technological activity, in support of innovating in the future. These mechanisms thus support firm innovative activity in the medium term. 
Strategic protection methods are strongly and positively associated with process innovation, both in persistent and sporadic forms, during 2004-2008. However, firms using strategic protection are more likely to introduce product innovation sporadically. Formal protections exert strong and significant effects on product innovation persistence, so firms adopting this mode of protection likely introduce process innovations sporadically. The results related to the science sources show that perceptions of knowledge sources from the past have strong, positive effects on the firm's ability to introduce product and process innovation, persistently over time. These results are in line with empirical research (e.g., Raymond et al., 2010) that uses information gathered from public and private institutions to control for proximity to science sources. Such studies highlight the crucial role of knowledge sources on technological innovation persistence.

The estimation results also suggest a significant, positive effect of competition intensity on sporadic product and process innovation, but we find no evidence of innovation persistence. This counterintuitive result might arise because competition has ambiguous effects on innovation: It is strong enough to trigger innovations but not enough to drive persistent innovation. Such an interpretation matches a modern view of the complex, inverted U-shaped relationship between the degree of competition and the intensity of innovation (Aghion et al., 2005). Belonging to a group does not affect product innovation persistence; it is likely to introduce sporadic process innovation though. The model also highlights the importance of firm size for explaining the persistence of technological innovation, in terms of both product and process innovations and in line with our hypothesis. To control for differences in the innovation profiles of different sub-sectors of activities, we introduced sub-sector dummies. Rather intuitively, more technologically advanced manufacturing industries (e.g., high-tech) were more likely to introduce product innovation in a persistent (or sporadic) manner during 2004-2008, but they were unlikely to display process innovation persistence. ${ }^{4}$ Also as expected, knowledgeintensive business services (KIBS), such as computer activities, were more likely to innovate continuously over time than were less knowledge-intensive sectors (e.g., wholesale trade). For our sample, we thus can confirm previous research that has highlighted the significant differences across sub-sectors of service activities.

\section{CONCLUSION AND SUGGESTIONS FOR RESEARCH}

Innovation persistence is an essential research topic for any relevant understanding of technological change dynamics and of firms' economic growth. We have surveyed extensive literature to identify the most important factors underlying firm innovation persistence. In addition to outlining the basic mechanisms that enable firms to sustain innovation over time, we have explored a promising new avenue for research that seeks to link organizational and technological innovations. Organizational innovation is a determinant of innovation persistence and, more generally, of technological innovation, in line with previous research (e.g., Mothe and

\footnotetext{
${ }^{4}$ It may be that they produce high value innovations on a sporadic basis.
} 
Nguyen-Thi, 2011). In our analysis of detailed organizational practices, we offer strong evidence that knowledge management is crucial for product innovation persistence; workplace organization undertaken in the past instead is associated with process innovation persistence.

A variable that lies at the core of innovation persistence is the link to R\&D activities. Our results confirm findings that firms with intensive $R \& D$ activity are more prone to innovate persistently in both products and processes. With respect to other classical determinants of innovation persistence, our results are in line with previous findings: Science sources and formal protection affect innovation persistence. In addition, with regard to sectors of activity, we find that, as expected, computer-related activities score high on product and process innovation persistence, whereas financial activities do not appear to relate to product innovation persistence. The specific findings pertaining to these two service sub-sectors suggest the need for more research into the differentiated characteristics and determinants of product versus process innovation persistence. The importance of other determinants, especially organizational innovation, leads us to acknowledge that $\mathrm{R} \& \mathrm{D}$ activities are becoming more complex.

As is true of all studies, this research is not without limitations. With our small sample, we cannot include too many explanatory variables in the model. Furthermore, our multinomial model does not account for dynamic mechanisms that might link various factors to firm behaviour.

With this analysis, we have attempted to explore the relevance of organizational innovation for patterns of technological innovation dynamics. Accordingly, this article complements previous literature by providing robust econometric support for the role and place of organizational innovation during innovation processes. It contributes to the economics of innovation dynamics by providing evidence in support of the belief that modern open innovation practices have moved beyond the traditional links between internal R\&D investments and innovation. In an open innovation paradigm, firms find innovation ideas through markets and external partnerships. This shift in the vision of innovation demands significant changes in the underlying organizational practices too. Innovation involves many factors, in addition to targeted R\&D (e.g., design is now a well-known source of technological improvement). Thus, firms' internal R\&D activities should not be confused with overall learning processes that provide a foundation for innovation. In this spirit, the influence of organizational change on technological innovation (and organizational innovation, as documented) needs further research attention.

The extensive data available through the CIS surveys suggest the promise of further progress in dealing with important issues related to innovation persistence. Some research topics deserve further analyses too. To date, the relationships between innovation persistence and firms' economic performance remain unknown. Researchers should investigate different persistence patterns adopted by complex (i.e., process and product) versus simple (i.e., process or product) innovators and thereby help identify the implications of innovation persistence in terms of technology and firm strategy. All these research improvements would have substantial implications for analyses of the sustainable dynamics of firms, industries, and regions. 


\section{References}

Aghion P., Bloom N., Blundell R., Griffith R. \& Howitt P., (2005), "Competition and Innovation: An Inverted-U Relationship", The Quarterly Journal of Economics, MIT Press, vol. 120(2), pages 701-728, May

Alänge, S. and Steiber, A. (2011), "Diffusion of organisational innovations: an empirical test of an analytical framework", Technology Analysis \& Strategic Management, Vol. 23 No. 8, pp. 881-897.

Antonelli, C. (2011), Handbook on the Economic Complexity of Technological Change, Edward Elgar, Cheltenham.

Antonelli, C., Crespi, F. and Scellato, G. (2010), "Inside Innovation Persistence: New Evidence from Italian Micro-data”, WP, University of Turin.

Antonelli, C., Crespi, F. and G. Scellato. 2012. Inside innovation persistence: New evidence from Italian micro-data, Structural Change and Economic Dynamics, Vol. 23 No. 4, pp. 341-353.

Armbruster, H., Bikfalvib, A., Kinkela, S. and Lay, G. (2008), "Organizational innovation: The challenge of measuring non-technical innovation in large-scale surveys", Technovation, Vol. 28, pp. 644-657.

Bharadwaj, S. and Menon, A. (2000), 'Making Innovation Happen in Organizations: Individual Creativity Mechanisms, Organizational Creativity Mechanisms or Both?', Journal of Product Innovation Management, Vol. 17 No. 6, pp. 424-434

Becerra-Fernandez, I. and Sabherwal, R. (2001), "Organizational knowledge management: A contingency perspective", Journal of Management Information Systems, Vol. 18 No. 1, pp. 2355 .

Bresnahan, T. F., Brynjolfsson, E. and Hitt, L. M. (2002), "Information technology, workplace organization and the demand for skilled labor: Firm-level evidence", The Quarterly Journal of Economics, Vol. 117 No. 1, pp. 339-376.

Cefis, E. (2003), "Is there any Persistence in Innovative Activities?", International Journal of Industrial Organization, Vol. 21 No. 4, pp. 489-515.

Cefis, E. and Ciccarelli, M. (2005), "Profit differentials and innovation", Economics of Innovation and New Technology, Vol. 14, pp. 43-61.

Chen, E. T., Feng, K. and Liou, W. (2004), "Knowledge management capability and firm performance: An empirical investigation", in Proceedings of the Tenth Americas Conference on Information Systems, August 5-8, New York, 2255-2262.

Clausen, T. H., Pohjola, M., Sapprasert, K. and Verspagen., B. (2010), “Innovation Strategies as a Source of Persistent Innovation”, working paper TIK, No. 20100617.

Cohen, W. M. and Levinthal, D. A. (1990), "Absorptive Capacity: A New Perspective on Learning and Innovation". Administrative Science Quarterly, Vol. 35 No.1, pp. 128-152.

Colombelli, A. and von Tunzelmann, N. (2011), "Persistence of innovation and path dependence", in C. Antonelli (Ed.), Handbook on the Economic Complexity of Technological Change, Edward Elgar, Cheltenham. 
Corrocher, N. Cusmano, L. and Morrison, A. (2009), "Modes of innovation in knowledgeintensive business services evidence from Lombardy", Journal of Evolutionary Economics, Vol. 19 No. 2, pp. 173-196.

Dosi, G. (1997) "Opportunities, incentives and the collective patterns of technological change", The Economic Journal, Vol. 107 No. 444, pp. 1530-1547.

Dougherty, D. (1992), "A practice-centered model of organizational renewal through product innovation", Strategic Management Journal, Vol. 13, pp. 77-92.

Duflos, G. (2006), "Persistence of Innovation, Technological Change and Quality-Adjusted Patents in the US Pharmaceutical Industry", Cahier de la MSE 2006.29.

Duguet, E. and Monjon, S. (2002), "Creative Destruction and the Innovative Core: Is Innovation Persistent at the Firm Level?", UCL Discussion Paper 02-07.

Duguet, E. and Monjon, S. (2004), Is Innovation Persistent at the Firm Level? An Econometric Examination Comparing the Propensity Score and Regression Methods. Université PanthéonSorbonne (Paris 1).

Flaig, G and M Stadler (1994). Success breeds success: The dynamics of the innovation process. Empirical Economics, 19, 55-68.

Evangelista, R. (2000), "Sectoral patterns of technological change in services", Economics of Innovation and New Technology, Vol. 9, pp. 183-221.

Evangelista, R. and Vezzani, A. (2010), "The economic impact of technological and organizational innovations. A firm-level analysis", Research Policy, Vol. 39 No. 10, pp. 12531263.

Flaig, G. and Stadler, M. (1994), "Success Breeds Success. The Dynamics of the Innovation Process", Empirical Economics, Vol. 19 No. 1, pp. 55-68.

Ganter, A. and Hecker, A. (2013), "Persistence of innovation: Discriminating between types of innovation and sources of state dependence", Research Policy, Vol. 42 No. 8, pp. 1431-1445.

Geroski, P., Van Reenen, J. and Walters, C.F. (1997), "How persistently do firms innovate?", Research Policy, Vol. 26, pp. 33-48.

Grant, R. M. (1996), "Prospering in dynamically-competitive environments: Organizational capability as knowledge integration”, Organization Science, Vol. 4, pp. 375-387.

Haned, N. (2011), Firm Performance, Sources and Drivers of Innovation and Sectoral Technological Trajectories. An Empirical Study on Recent French CIS, Thèse de sciences économiques, Université Lumière Lyon 2.

Henderson, R. M. and Clark, K. B. (1990), "Architectural innovation: The reconfiguration of existing product technologies and the failure of established firms", Administrative Science Quarterly, Vol. 35 No. 1, pp. 9-22.

Huang, C.-H. (2008), "A note on the persistence of firms' innovation behavior: A dynamic random effect probit model approach", Economics Bulletin, Vol. 15 No. 5, pp. 1-9.

Huang, C.-H. and Yang, C.H. (2010), "Persistence of innovation in Taiwan's manufacturing firms", Taiwan Economic Review, Vol. 38 No. 2, pp. 199-231. 
Ichniowski, C., Shaw, K. and Prenushi, G. (1997), "The effects of human resource management practices on productivity: A study of steel finishing lines", American Economic Review, Vol. 87, pp. 291-313.

Johansson, B. and Lööf, H. (2010), "Innovation Strategy and Firm Performance. What is the Long-Run Impact of Persistent R\&D?", working paper, Series in Economics and Institutions of Innovation 240, Royal Institute of Technology, CESIS - Centre of Excellence for Science and Innovation Studies.

Klomp, L. and van Leeuwen, G. (2001), "Linking innovation and firm performance: A new approach", International Journal of the Economics of Business, Vol. 8 No. 3, pp. 343-64.

Kremp, E. and Mairesse, J. (2004), "Knowledge Management, Innovation and Productivity: A Firm Level Exploration Based on French Manufacturing CIS3 Data", NBER working paper 10237.

Latham, W and C Le Bas (eds.) (2006). The economics of persistent innovation: an evolutionary view, Springer. Berlin.

Le Bas, C. and Poussing, N. (2013), "Is Complex Innovation More Persistent than Single? An Empirical Analysis of Innovation Persistence Drivers", International Journal of Innovation Management (forthcoming).

Le Bas C. and Scellato, G. (2013), "Firm innovation persistence: a fresh look on the frameworks of analysis", Economics of Innovation and New Technology, forthcoming.

Le Bas, C., Cabagnols, A. and Gay, C. (2003), "An evolutionary view on persistence in innovation: An empirical application of duration models", in P. Saviotti (Ed.) Applied Evolutionary Economics: New Empirical Methods and Simulation Techniques. INRA-SERD, Pierre Mendès University, Grenoble and IDEFI-CNRS-UNSA Sophia-Antipolis, France.

Lelarge, C. (2006), Les entreprises industrielles françaises sont-elles à la frontière technologique?, Revue Economique, Vol. 57 No. 3, pp. 473-484.

Lokshin, B., van Gils, A. and Bauer, E. (2008), "Crafting Firm Competencies to Improve Innovative Performance", working paper, UNU-MERIT.

Love, J. H. and Mansury, M. A. (2007), "External linkages, R\&D and innovation performance in US business services", Industry and Innovation, Vol. 14 No. 5, pp. 477-496.

Máñez Castillejo, J. A., Rochina Barrachina, E., Sanchis Llopis, Z. and Sanchis Llopis, J.A. (2004), "A dynamic approach to the decision to invest in R\&D. The role of sunk costs", working paper.

Mothe, C. and Nguyen-Thi, T.U. (2010), "The link between non technological innovations and technological innovation", European Journal of Innovation Management, Vol. 13 No. 3, pp. 313-332.

Mothe, C. and Nguyen-Thi, T.U. (2012), "Non-technological and technological innovations: Do services differ from manufacturing? An empirical analysis of Luxembourg firms", International Journal of Technology Management, forthcoming.

Musolesi, A. (2006), Dynamique de l'innovation dans les services français, working paper, No. 2006-06, Laboratoire d'Economie et de Gestion, CNRS. 
Nelson, R. and Winter, S. (1977), "In search of useful theory of innovation", Research Policy, Vol. 6, pp. 36-76.

OECD, (2001), Science and Technology Industry Scoreboard 2001. Paris.

OECD, (2005), The Measurement of Scientific and Technological Activities - Proposed Guidelines for Collecting and Interpreting Technological Innovation Data. Oslo Manual. Paris.

Pavitt, K. 2003. “The Process of Innovation”, working paper SPRU, No. 89. August.

Peters, B. (2009), "Persistence of innovation: Stylised facts and panel data evidence", The Journal of Technology Transfer, Vol. 34 No. 2, pp. 226-243.

Prahalad, C. K. and Hamel, G. (1990), "The core competence of the corporation", Harvard Business Review, Vol. 3, pp. 79-91.

Raymond, W., Mohnen, P., Palm, F. and van der Loeff, S. (2010), "Persistence of innovation in Dutch manufacturing: Is it spurious?", Review of Economics and Statistics, Vol. 92, pp. 495504.

Roper, S. and Hewitt-Dundas, N. (2008), "Innovation persistence: Survey and case-study evidence", Research Policy, Vol. 37, pp. 149-162.

Shin, M. (2004), "A framework for evaluating economics of knowledge management systems", Information and Management, vol. 42, pp. 179-196.

Smith K. H. (2005), Measuring innovation, in The Oxford Handbook of Innovation, Oxford University Press, New York, US, pp. 148-177.

Spicer, D. P. and Sadler-Smith, E. (2006), "Organizational learning in smaller manufacturing firms”, International Small Business Journal, Vol. 24 No. 2, pp. 133-158.

Triguero-Cano, A. and Córcoles-González, D. (2010), "Understanding the innovation: An analysis of persistence for Spanish manufacturing firms", paper presented at the Twelfth Annual Conference ETSG, 9-11 September 2010, Lausanne.

Uhlaner, L., Wright, M. and Huse, M. (2007), "Private firms and corporate governance: An integrated economic and management perspective", Small Business Economics, Vol. 29, pp. 225-241.

Von Hippel, E. (1988), The Sources of Innovation, Oxford University Press. 